\title{
A NEW SPECIES OF CYATHURA (ISOPODA, ANTHURIDAE) FROM FRESH WATER IN SHANGHAI, P.R. CHINA
}

\author{
BY
}

\author{
WENLIANG LIU ${ }^{1,2}$ ), GARY C. B. POORE ${ }^{3}$ ) and XIAOHUA CHEN ${ }^{4,5}$ ) \\ ${ }^{1}$ ) The State Key Laboratory of Estuarine and Coastal Research, East China Normal University, \\ Shanghai 200062, P.R. China \\ 2 ) Shanghai Key Lab for Urban Ecological Processes and Eco-Restoration, College of Resources \\ and Environmental Science, East China Normal University, Shanghai 200062, P.R. China \\ 3 ) Museum Victoria, GPO Box 666, Melbourne, VIC 3000, Australia \\ $\left.{ }^{4}\right)$ Shanghai Academy of Environmental Sciences, Shanghai, 200203, P.R. China
}

\begin{abstract}
Anthurid isopods collected from the river courses in Shanghai, China, are described as a new species, Cyathura shanghaiensis, representing the first record of the genus in fresh waters of China.

\section{RÉSUMÉ}

Des isopodes Anthuridés, collectés dans les cours d'eau à Shangai, Chine, sont décrits comme une espèce nouvelle : Cyathura shanghaiensis sp. n., représentant le premier signalement du genre Cyathura dans les eaux douces de Chine.
\end{abstract}

\section{INTRODUCTION}

The anthurid isopod genus Cyathura Norman \& Stebbing, 1886 is cosmopolitan, except for polar regions. Most of its 30 species are coastal with several occurring in estuarine and freshwater habitats (Schotte et al., 1995 onwards, 2008 onwards; Poore, 2001). One species, Cyathura peirates Bamber, 2008, has been reported from the littoral of Hong Kong. While working on the systematic study of the benthic fauna of Shanghai city a new species was found in the Dazhenggang River, the first record in fresh water of China.

All material examined is deposited in the State Key Laboratory of Estuarine and Coastal Research, East China Normal University, Shanghai, China. The drawings were made with the aid of drawing tube mounted on a Zeiss V8 compound microscope (magnification: 6.3-300×).

5) Corresponding author; e-mail: shoutfar@yahoo.com.cn

(C) Koninklijke Brill NV, Leiden, 2013 


\section{SYSTEMATICS}

Family ANTHURIDAE Leach, 1814

Genus Cyathura Norman \& Stebbing, 1886

Cyathura shanghaiensis sp. nov.

(figs. 1-3)

Material examined.- Holotype: $\sigma^{\top}$ (total length, $12.5 \mathrm{~mm}$ ), CWRC 20110711-1, Dazhenggang River, Shanghai $\left(30.96^{\circ} \mathrm{N} 121.02^{\circ} \mathrm{E}\right)$, depth $4 \mathrm{~m}$, bottom mud, coll. Xiaohua Chen, by Petersen Grab $\left(1 / 32 \mathrm{~m}^{2}\right)$, 11 July 2011. Paratype: $\sigma^{7}$ (head to pereonite 4 missing), collected with holotype.

Description.- Male. Body (fig. 1A) slender, 9 times as long as wide. Integument smooth, with dense fine setae all over; shallow dorsal pits on pereonites 4-6. Head (fig. 1B) about as long as wide; rostrum almost as long as lateral lobes, truncate; without eyes. Dorsolateral margins of pereonites 4-7 produced as small lobes posterior to base of legs. Pereonites 1-7 respectively 1.6, 1.2, 1.1, 1.2, 1.0, 0.5 and 0.8 times as long as wide, pereonite 4 longest. Pleon 1.2 times as long as pereonite 7 , about as long as wide; pleonites 1 to 5 fused, pleonite 6 distinct with posterior split in mid-line. Telson (fig. 1E) flat, 2.3 times as long as wide and 1.3 times as long as pleon, with 2 basal statocysts; lateral margins parallel, finely setose.

Antennule (fig. 1C) reaching midway along article 5 of antenna; article 1 with numerous fine inner setules, article 2 with outer row of 7 setae longer than article width; flagellum of 4 articles, first very short, naked, second longest (twice as long as other 3 articles together), third and fourth articles small, third naked, fourth with several distal setae and 3 aesthetascs. Antenna (fig. 1D) peduncle article 2 longest; article 3 with numerous fine inner setules; third and fourth articles subequal, fifth a quarter longer with numerous distal setae; flagellum of 4 articles, second longest, distal articles with numerous fine setae.

Mandibular molar (fig. 3A) narrow, truncate; lamina dentata with 12 saw-teeth, incisor blunt; palp 3-articled, with numerous fine setae predominantly along outer margin; article 1 about 2.4 times as long as wide, article 2 about 1.4 times as long as article 1, with 3 long inner setae; article 31.2 times as long as article 1 with several short inner setae and 6 terminal pectinate setae. Maxilla (fig. 3B) with strong distal and four subdistal teeth blunt. Maxilliped (fig. 3C) covered with fine hairs, basal endite obsolete; fused articles 3-4 with 2 mesial setae; fused articles 4-5 oblique, about 0.4 times length of 3-4, with 4 mesial setae.

Pereopod 1 (fig. 2A) robust, subchelate; basis swollen, 1.8 times as long as wide, extensor margin convex in middle, with dorsal row of setules and 3 setae; ischium 0.8 times as long as basis with dense row of setae on flexor margin; merus 2.4 times as wide as long, without conspicuous spinose apophysis; carpus triangular, with fine setules and row of setae along flexor margin, distally not extended; propodus 


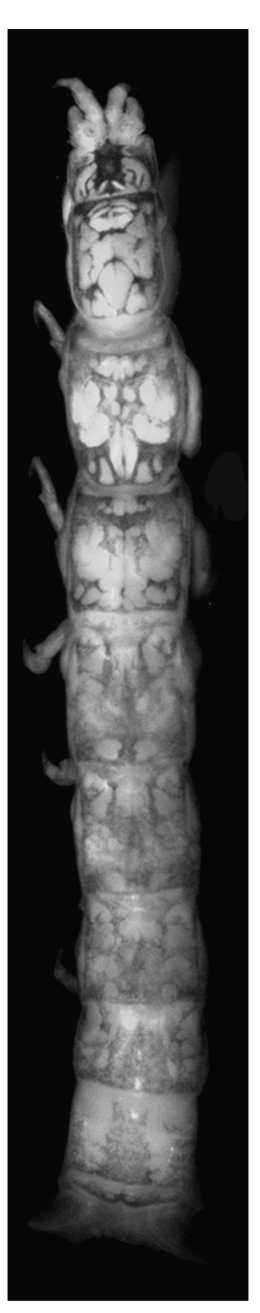

A

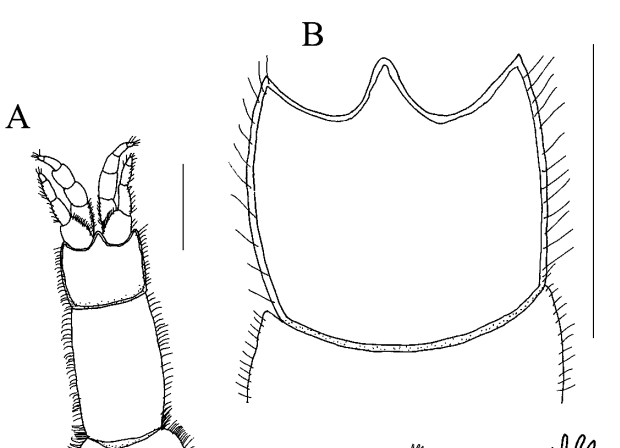

B
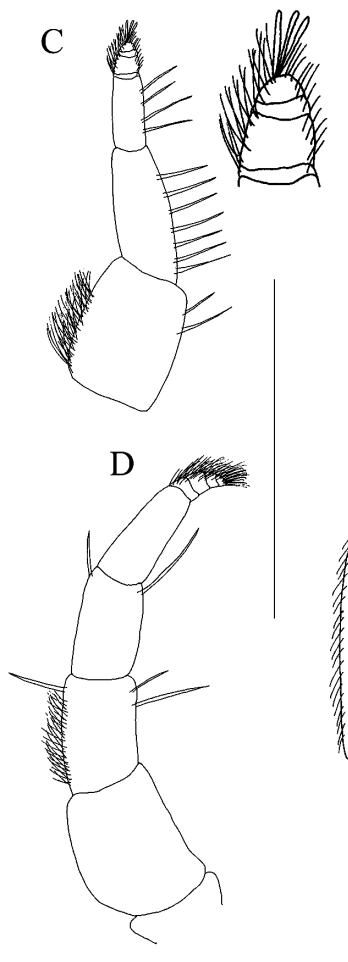

$\mathrm{E}$
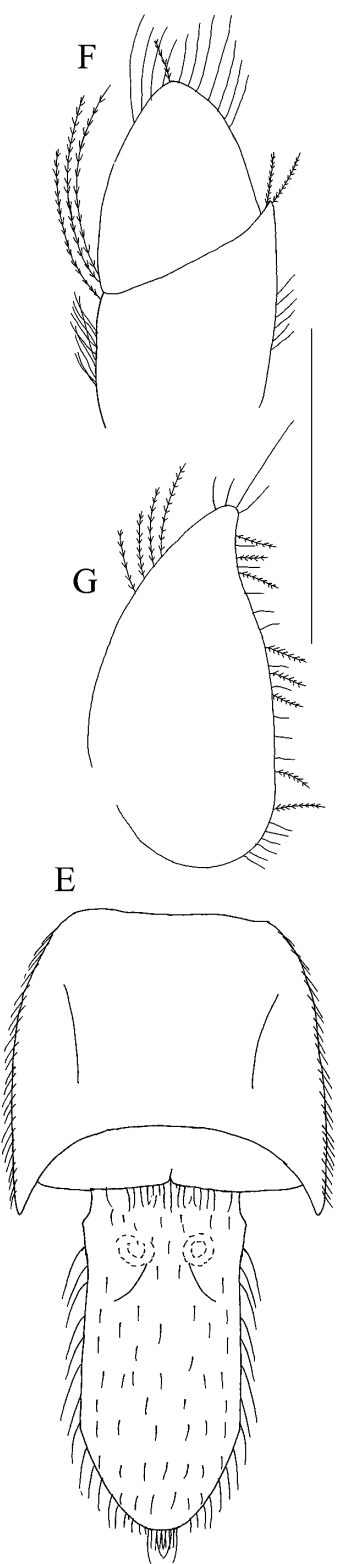

Fig. 1. Cyathura shanghaiensis sp. nov. Holotype male. A, male holotype, dorsal view; B, head; C, antennule and detail of tip; D, antenna; E, telson; F, uropod endopod; G, uropod exopod. Scale = $1 \mathrm{~mm}$.

bulbous, 1.8 times as long as wide, extensor margin with sparse row of setae, flexor margin with numerous fine setules, palm with conical tooth at midpoint; dactylus 0.4 times as long as propodus, extensor margin with row of setules; unguis 0.2 times length of whole. 


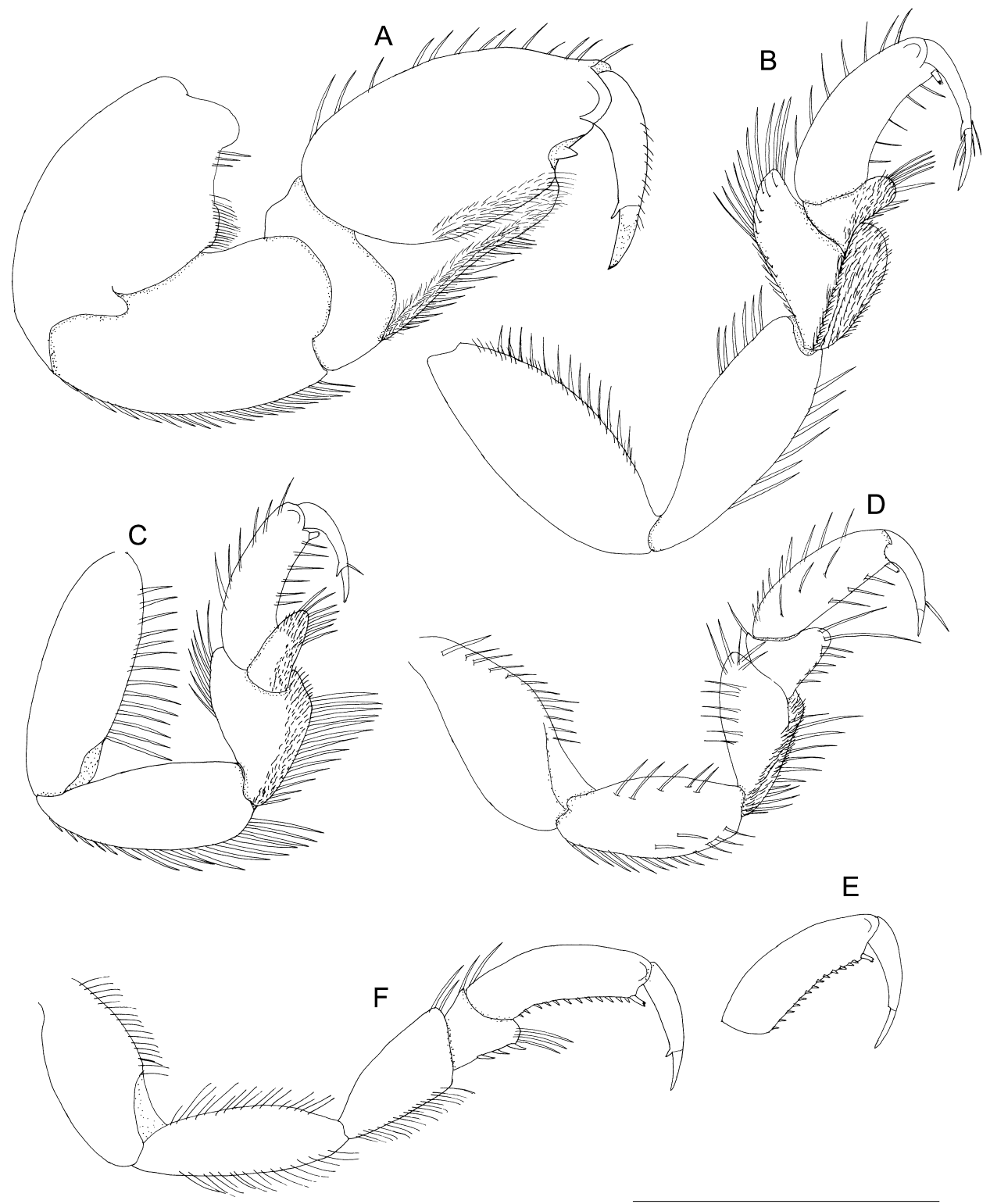

Fig. 2. Cyathura shanghaiensis sp. nov. Holotype male. A-F, pereopods 1-3, 5-7. Scale $=1 \mathrm{~mm}$.

Pereopods 2 and 3 (fig. 2B, C) similar; basis with row of setae on extensor margin; ischium subequal to basis, with row of setae on flexor margin; merus lobed on flexor margin, with rows of long setae along both margins, and numerous fine setules on lobe; carpus distally lobed, lobe setose and setulose; propodus cylindrical, curved, with rows of setae along both margins, with stout denticulate seta on distal palm; dactylus with unguis 0.3 of whole. 
Pereopods 4-6 of similar size, with stout denticulate seta distally on propodus, lacking a secondary unguis on dactylus. Pereopods 4 and 5 (fig. 2D) basis with row of long setae on extensor margin; ischium and merus with long setae along flexor margin and extensor submargin; merus with setulose flexor margin. Pereopod 6 (fig. 2E) propodus palm with row of 14 short robust setae, last one pectinate. Pereopod 7 (fig. 2F) slender, with longer propodus than more anterior limbs; basis 2.0 times as long as wide with row of fine setules along extensor margin; ischium almost as long as basis, with rows of fine setules along both margins; merus 0.7 times as long as ischium, with row of fine setules on flexor margin, 2 distal setae on flexor margin; carpus 0.3 times as long as merus, with 3 robust setae and 2 simple setae on flexor margin, 2 simple setae distally on extensor margin; propodus 3.5 times as long as wide, longer than more anterior limbs, palm with row of 12 robust setae and 1 pectinate seta.

Pleopod 1 (fig. 3D) exopod operculiform, with about 40 marginal plumose setae; endopod 0.7 times length of exopod, without setae. Pleopod 2 (fig. 3E) with similar arrangement of setae, appendix masculina shorter than endopod, slightly distally dilated.

Uropod endopod (fig. 1F) reaching beyond end of telson, 1.9 times as long as wide, widest proximally; exopod (fig. 1G) 1.9 times as long as wide, margin slightly concave distally, bearing plumose setae and few longer simple setae.

Etymology.- The species name is derived from the type locality, Shanghai city.

Remarks. - Although incomplete, the paratype cannot be distinguished from the holotype. The holotype displays typical male features besides the presence of an appendix masculina. But the simple and relatively short appendix masculina could indicate that the male may be immature. Pereopods 2 and 3 have curved propodi and the flexor margins of pereopods 1-3 are ornamented with a mat of setules. The female is unknown.

The only other species of Cyathura from China, C. peirates, is also pigmented. Other species from the northwestern Pacific margin include seven from Japan and one from Vietnam. Of these, C. furcata Nunomura \& Hagino, 2000, C. higoensis Nunomura, 1977, C. kikuchii Nunomura, 1977, C. muromiensis Nunomura, 1974, C. sagamiensis Nunomura, 2006 and $C$. shijikoensis Nunomura, 2001, known from Japan, are illustrated with a complex apex on the appendix masculina. The new species has a simpler appendix masculina apex than any species illustrated to date. In as far as the illustrations of these species can be relied on, these species and the others from the region, C. omorii Nunomura, 1992, known from Japan, and C. truncata Dang, 1965, known from Vietnam, differ in coloration, body or limb proportions or telson shape. Most of these were reported from estuaries. Only $C$. furcata is from fresh water like the new species. The southern Australian species, 

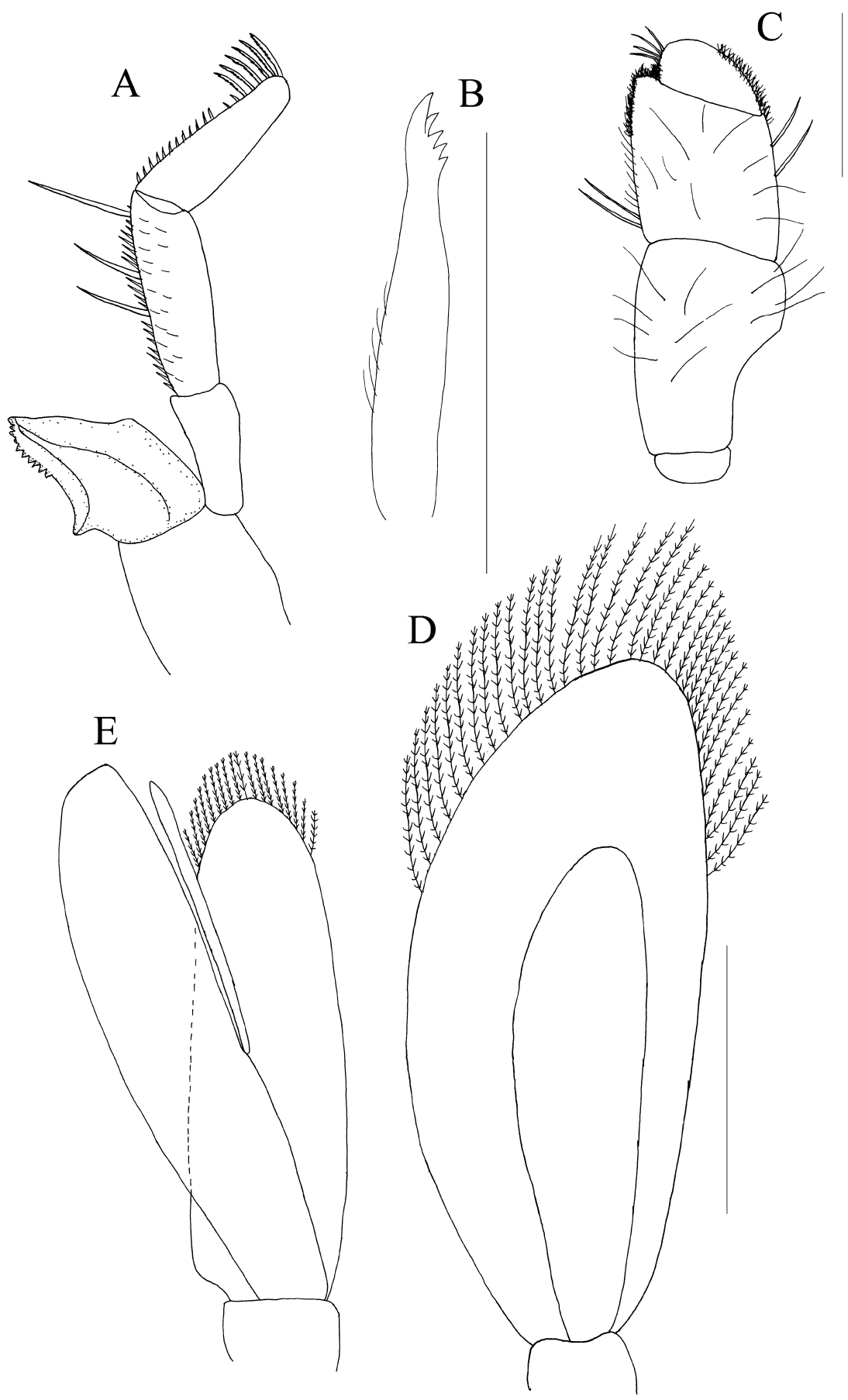

Fig. 3. Cyathura shanghaiensis sp. nov. Holotype male. A, mandible; B, maxilla; C, maxilliped; D-E, male pleopods 1-2 (representative setae only shown). Scale $=1 \mathrm{~mm}$ for A, C-E; $0.5 \mathrm{~mm}$ for B. 
C. hakea Poore \& Lew Ton, 1985 occurs in both estuaries and fresh water coastal lakes.

\section{ACKNOWLEDGEMENTS}

This work was supported by the Special Fund for Young Scientists of Shanghai Environmental Protection Bureau (Grant No. SHES 2011-04) and the Innovate Foundation of East China Normal University (Grant No. 78210097). The first author sincerely appreciates his teacher, the great carcinologist, the late Professor Ruiyu Liu (J. Y. Liu) (Institute of Oceanology, Chinese Academy of Sciences) for his considerable guidance in carcinology research.

\section{REFERENCES}

BAMBER, R. N., 2008. New species of anthurid and arcturid isopod (Crustacea: Peracarida: Isopoda) from Hong Kong. Journal of Natural History, 42: 855-876.

DANG, N. T., 1965. Mot so loai giap xac moi tim thay trong nuroc ngot va nuroc lo mien Bac Viet-Nam. Tap San Sinh Vat-Dia Hoc, 4: 146-152.

Norman, A. M. \& T. R. R. Stebiing, 1886. On the Crustacea of the 'Lighting', 'Porcupine' and 'Valorous' expeditions. Transactions of the Zoological Society of London, 12: 77-141.

Nunomura, N., 1974. A new anthurid isopod from the estuary of the Muromi river, Northern Kyushu, Japan. Bulletin of the Osaka Museum of Natural History, 28: 13-16.

— _, 1977. Marine Isopoda from Amakusa, Kyushu (I). Publications of the Amakusa Marine Biological Laboratory, 4: 71-90.

—, 1992 . Anthuridea (Crustacea: Isopoda) from the Ryukyu Archipelago. Bulletin of the Toyama Science Museum, 15: 47-56.

— - 2001. A new species of the genus Cyathura (Crustacea: Isopoda) from the Lake Shinji-ko, Shimane Prefecture, western Japan. Bulletin of the Toyama Science Museum, 24: 19-23.

Nunomura, N. \& M. Hagino, 2000. A new species of the genus Cyathura from Lake Kasumigaura, Ibaraki Prefecture, Japan. Bulletin of the Toyama Science Museum, 23: 5-9.

Poore, G. C. B., 2001. Families and genera of Isopoda Anthuridea. In: B. Kensley \& R. C. BRUSCA, Isopod systematics and evolution. Crustacean Issues, 13: 63-173. (Balkema, Rotterdam).

Poore, G. C. B. \& H. M. LEW TON, 1985. New species of Cyathura (Crustacea: Isopoda: Anthuridae) from estuaries of eastern Australia. Memoirs of the Museum of Victoria, 46: 89101.

Schotte, M., B. Kensley \& S. Shilling, 1995 onwards. World list of marine, freshwater and terrestrial Crustacea Isopoda. National Museum of Natural History Smithsonian Institution, Washington. Available online at http://www.nmnh.si.edu/iz/isopod/.

Schotte, M., C. B. Boy Ko, N. L. Bruce, G. C. B. Poore, S. Taiti \& G. D. F. Wilson, 2008 onwards. World list of marine freshwater and terrestrial isopod crustaceans. Available online at http://www.marinespecies.org/isopoda. 